Sonic Scope: New Approaches to Audiovisual Culture

\title{
Chara Stergiou - What is a \\ "DJ Lecture"?: Uprooting \\ Sovereignties of \\ Knowledge Through \\ Montaging Songs
}

Chara Stergiou

Published on: Feb 15, 2021

DOI: $10.21428 / 66 f 840 a 4 . e d f 376 a c$

License: Creative Commons Attribution 4.0 International License (CC-BY 4.0). 


\section{What is a "DJ Lecture"?: Uprooting Sovereignties of Knowledge Through Montaging Songs}

Chara Stergiou, Goldsmiths, University of London

DJ

1. Someone who plays records and talks on the radio or at an event where people dance to recorded popular music, such as a nightclub.

2. By dramatically emphasising the connections between songs, by juxtaposing them or seamlessly overlaying them, the modern club $\mathrm{DJ}$ is not so much presenting discrete records as combining them to make something new. $\underline{2}$

\section{Lecture}

1. A formal talk on a serious subject given to a group of people, especially students.

2. An angry or serious talk given to someone in order to criticize their behaviour. $\underline{3}$

In the past couple of years, I instinctively developed what I call a "DJ Lecture." 4 It is a DJ set performed as lecture or a lecture performed as a DJ set. In other words, a collection of songs and theoretical references interwoven and performed in order to tell a unique story. It all started during the preparation of my contribution to a public event of the Ocean as Archive class of 2018-2019 in the MA CAT at Goldsmiths. I needed to speak of an often unacknowledged, speculative but very real and oppressed self of the Greek subjectivity as shaped after the 1990s following its introduction to a capitalist reality. Such intense concerns would have been better corresponded as an embodied experience rather than in a regular talk format.

\section{Song As a Medium of Affect}

Songs are complete oeuvres. Sonorous and lyrical artefacts that encapsulate stories which are often hard to express effectively in plain words. With no clear primary intention in mind, I started to 
construct a journal of songs that related to the weekly topics of the course: sonic stories of oppression and the sea through recent samples of Greek popular music. Influenced by a very intense concert I attended at that time, it was clear to me that there is a particular collective sentimentality that a live performance can offer to its audience. Just a three-minute piece of performed music could shake immediately the grounds of our collective unconscious better than any other "sovereign of knowledge" could do. $\underline{5}$ A song as a medium works literally as an affective transmitter which embodies social experience. Sociopolitical registers and psychographs of one's self could emerge as well through its lyricism while sometimes functioning as a provider of small doses of "the structure of feeling" of a population at certain moments of time. $\underline{6}$ Better than formal history, richer in feeling of a social experience.

\section{DJ Lecture: A Modus Operandi}

A DJ Lecture is based on a set of bibliographical references/samples we usually hear in a typical lecture and a heterogeneity of song samples of diverse aesthetic style that attempt to speak of a fictional but very real social imaginary. From rock to hip-hop, techno and folk music, to new wave and experimental pieces, the only canon there was the date of production of the songs and, mostly, their lyricism, therefore, their capacity to create affect. Different songs, different styles, different stories. However, wasn't this kind of fragmentary sampling and heterogenenity one of the actual powers of DJ-ing?

\section{DJing: A Montage Based on Creating Affect}

first appearance, the word 'Disc Jockey' primarily obtained a dismissive hue describing the person music selector - who replaced the live music played on radio. $\underline{7}$ Today, the $\mathrm{D}$ J is a metamusician. $\underline{8}$ The "epitome of the postmodern artist" who makes musical collages while also being a "post-producer" who "selects cultural objects inserting them into new contexts" being a kind of a magician playing with the feelings of an audience in a room and handling its atmosphere. $\underline{9}$

A song alone may tell a story, but playing with the setlist (in our case a sonic and a verbal one), selecting and montaging its order, a unique story of a speculative nature can emerge which, in the case of the DJ Lecture, can break the grounds of an "anhedonistic" academia. $\underline{10}$ If a lecture is "a formal talk on a serious subject" then, let's play with this formality and make our unsound stories "serious" and more "real." $\underline{11}$ Or, even if a lecture is "an angry talk given to someone in order to criticise their behaviour," then why not express collective and unacknowledged resentment and anger before it becomes grief? $\underline{12}$ 


\section{Bibliography}

Brewster, Bill, and Frank Broughton. Last Night a DJ Saved My Life: The History of the Disc Jockey. New York: Grove Press, 2000.

Bourriaud, Nicolas. Post Production. Culture as Screenplay: How Art reprograms the world. New York: Sternberg Press, 2002.

Cambridge Dictionary. “Disc Jockey.” Accessed January 30, 2021.

https://dictionary.cambridge.org/dictionary/english/disc-jockey.

Cambridge Dictionary. “Lecture.” Accessed January 30, 2021.

https://dictionary.cambridge.org/dictionary/english/lecture.

Colquhoun, Matt. “Appendix Two: 'No More Miserable Mornings' Tracklist." In Postcapitalist Desire: The Final Lectures, edited by Matt Colquhoun, 217-220. London: Repeater Books, 2020.

Harney, Stefano and Fred Moten. The Undercommons: Fugitive Planning \& Black Study. New York: Minor Compositions, 2013.

Sputnik, Charlie. DJ Techniques: Vinyl and Digital. Milwaukee: Hal Leonard, 2018.

Wark, McKenzie. Sensoria: Thinkers of the 21st Century. London: Verso, 2020.

Williams, Raymond. Marxism and Literature. Oxford: Oxford University Press, 1977.

\section{Media Cited}

Chara Stergiou. "Music for Amphibious Populations." YouTube video, 13:35. January 26, 2020. Accessed January 30, 2021. https://www.youtube.com/watch?v=SSVY4dFqI-I\&feature=youtu.be.

Chara Stergiou."Music for Logistical Populations." YouTube video, 9:27. May 4, 2019. Accessed January 30, 2021. https://www.youtube.com/watch?v=08Do0gcwyeg.

Stefano Harney. "Stefano Harney on Study." YouTube video, 5:27. July 21, 2018. Accessed January 30, 2021. https://www.youtube.com/watch?v=uJzMi68Cfw0\&t=1s. 


\section{Footnotes}

1. “Disc Jockey," Cambridge Dictionary, accessed January 30, 2021, https://dictionary.cambridge.org/dictionary/english/disc-jockey. $\boxminus$

2. Bill Brewster and Frank Broughton, Last Night a DJ Saved My Life: The History of the Disc Jockey (New York: Grove Press, 2000), 17. $\subseteq$

3. "Lecture," Cambridge Dictionary, accessed January 30, 2021, https://dictionary.cambridge.org/dictionary/english/lecture. $\subseteq$

4.

For examples of a DJ Lecture, see:

Chara Stergiou, "Music for Logistical Populations," May 4, 2019, accessed January 30, 2021, https://www.youtube.com/watch?v=08Doogcwyeg;

Chara Stergiou, "Music for Amphibious Populations," January 26, 2020, accessed January 30, 2021, https://www.youtube.com/watch?v=SSVY4dFqI-I\&feature=youtu.be. $\triangleq$

5.

Many thinkers such as Fred Moten and Stefano Harney, and McKenzie Wark have developed certain reflections on the notion of 'study' and possible emancipatory practices as a comment on contemporary scholarship and the modes of knowledge production related to a tendency of disciplines claiming a kind of 'sovereignty' over objects of knowledge.

Stefano Harney and Fred Moten, The Undercommons: Fugitive Planning \& Black Study (New York: Minor Compositions, 2013), 114-117;

Stefano Harney, “Stefano Harney on Study," July 21, 2018, accessed January 30, 2021, https://www.youtube.com/watch?v=uJzMi68Cfw0\&t=1s;

McKenzie Wark, Sensoria: Thinkers of the 21st Century (London: Verso, 2020), 1-8.

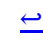

6. Raymond Williams, Marxism and Literature (Oxford: Oxford University Press, 1977), 128-135. 7. Charlie Sputnik, DJ Techniques: Vinyl and Digital (Milwaukee: Hal Leonard, 2018), $11 . \triangleq$ 
8. Brewster and Broughton, Last Night a DJ Saved My Life, 22. $ヒ$

9.

Ibid.;

Nicolas, Bourriaud, Post Production. Culture as Screenplay: How Art Reprograms the World (New York: Sternberg Press, 2002).

10.

In a different context, Matt Colquhoun makes a use of the word "anhedonia" in the university which -10 even used in a different context and for a different purpose - I find very fruitful even to its literary use as to describe a lack of desire towards the way contemporary scholarship and knowledge production take place.

Matt Colquhoun, "Appendix Two: 'No More Miserable Mornings' Tracklist," in Postcapitalist Desire: The Final Lectures, ed. Matt Colquhoun (London: Repeater Books, 2020), 217. $\doteq$

11.

Definition found in Cambridge Dictionary,

https://dictionary.cambridge.org/dictionary/english/lecture $\underline{-}$

12. Ibid. 